\author{
Michat Marszelewski \\ Uniwersytet Mikołaja Kopernika, Torun \\ marszelewski@gmail.com \\ Patryk Piątkowski \\ Uniwersytet Mikołaja Kopernika, Torun \\ partykpiatkowski92@o2.pl
}

\title{
Wpływ dyrektywy w sprawie dystrybucji ubezpieczeń na krajowy rynek pośrednictwa ubezpieczeniowego. Zagadnienia wybrane
}

DOI: http://dx.doi.org/10.12775/SIT.2016.018

\section{Wprowadzenie}

Dnia 20 stycznia 2016 r. została przyjęta Dyrektywa Parlamentu Europejskiego i Rady (UE) 2016/97 w sprawie dystrybucji ubezpieczeń (ang. Insurance Distribution Directive) ${ }^{1}$. Przedmiotowy akt wszedł w życie 23 lutego 2016 r., co oznacza, iż państwa członkowskie muszą dokonać jego implementacji do krajowych porządków normatywnych do dnia 23 lutego 2018 r.

${ }^{1}$ Dz.Urz. UE L 26 z 02.02.2016 r., dalej cyt.: dyrektywa dystrybucyjna. Przedmiotowy akt pierwotnie nazywany był Insurance Mediation Directive 2 (IMD2), lecz we wrześniu 2014 r. zdecydowano się zmienić jego nazwę na Insurance Distribution Directive, co silnie akcentuje fakt dystrybucji ubezpieczeń, a nie pośrednictwo w tym zakresie. 
Prezentowana dyrektywa, co oczywiste, jest szeroko komentowana w branży ubezpieczeniowej. Zmiana istniejącego modelu pośrednictwa ubezpieczeniowego na model świadczenia usług dystrybucyjnych - jak wielokrotnie podkreślono - może stanowić zachętę dla krajowego ustawodawcy do istotnego przekształcenia rynku, a w skrajnym przypadku odejścia od utrwalonego przez lata podmiotowego podziału na agentów i brokerów.

Jednocześnie warto podkreślić, iż polski rynek pośrednictwa ubezpieczeniowego obejmuje kilkadziesiąt tysięcy podmiotów i per se nie wymaga koniecznej ingerencji czy przebudowy. Zgodnie $z$ danymi Komisji Nadzoru Finansowego na koniec grudnia 2014 r. było 1224 brokerów (osób fizycznych i osób prawnych), a zakłady ubezpieczeń - tylko w 2014 r. - wypłaciły im ponad 900 mln zł prowizji $^{2}$. Z kolei - również na dzień 31 grudnia 2014 r. - w prowadzonym w formie elektronicznej rejestrze agentów ubezpieczeniowych wpisanych było 33685 agentów oraz 176586 osób wykonujących czynności agencyjne ${ }^{3}$. Przytoczone liczby świadczą o praktycznej doniosłości analizowanego zagadnienia, a ewentualne - większe niż konieczne, tj. wynikające $z$ przepisów dyrektywy dystrybucyjnej - zmiany mogą doprowadzić do niepożądanych skutków na rynku pośrednictwa, zwłaszcza iż omawiana dyrektywa w pkt 5 preambuły expressis verbis stanowi, że dystrybucją ubezpieczeń mogą zajmować się m.in. brokerzy i agenci.

\section{Charakterystyka i cel przyjęcia dyrektywy dystrybucyjnej}

Wśród motywów, którymi kierował się europejski prawodawca, przyjmując nową regulację, należy wyróżnić przede wszystkim potrzebę harmonizacji krajowych przepisów dotyczących dystrybucji

${ }^{2}$ Urząd Komisji Nadzoru Finansowego, Raport o stanie rynku brokerskiego w 2014 r., Warszawa 2015, s. 3.

3 „Gazeta Ubezpieczeniowa”, KNF: Ponad 200 tys. agentów i OWCA w 2014 r., http:/ /www.gu.com.pl/index.php?option=com_content\&view=article\&id=557 19:2015-03-18-07-32-07\&catid=99:porednictwo\&Itemid=102 (dostęp: 10.07. 2016 r.). 
ubezpieczeń i reasekuracji ${ }^{4}$ oraz konieczność koordynacji krajowych przepisów dotyczących warunków podejmowania działalności w zakresie dystrybucji ubezpieczeń (pkt 2 preambuły dyrektywy dystrybucyjnej). Ponadto dyrektywa ma prowadzić do zwiększenia efektywności i pewności dystrybucji produktów ubezpieczeniowych, jak również zapewnienia jednakowego, wysokiego i porównywalnego poziomu ochrony konsumentów, bez względu na kanał dystrybucji ubezpieczeń, przy jednoczesnym uwzględnieniu różnic w rodzajach kanałów dystrybucji ${ }^{5}$. $Z$ tego powodu omawiany akt wpisuje się $\mathrm{w}$ bardzo popularny ostatnio ${ }^{6}$ nurt prokonsumencki $\mathrm{w}$ prawie

${ }^{4}$ W kontekście działań zmierzających do ujednolicenia przepisów dotyczących m.in. praw i obowiązków stron umowy ubezpieczenia, a w rezultacie zapewnienia jednolitej, w skali Europy, ochrony ubezpieczającego (ubezpieczonego, uprawnionego do świadczeń z umowy ubezpieczenia) należy wskazać także projekt instrumentu opcjonalnego - Zasady Europejskiego Prawa Ubezpieczeń - Project Group "Restatement of European Insurance Contract Law”, The Principles of European Insurance Contract Law (PEICL), https:// www.uibk.ac.at/zivilrecht/forschung/evip/restatement/draft.html (dostęp: 16.07.2016 r.), dalej cyt.: PEICL. Podobna inicjatywa została przedsięwzięta w stosunku do umów reasekuracji, co ma zaowocować projektem regulacji o nazwie „Principles of Reinsurance Contract Law” (PRICL), zob. Project Group "Principles of Reinsurance Contract Law" Report on the 1st Workshop, January 27-30 Zurich, https://www.editoraroncarati.com.br/v2/phocadownload/ reuniao_zurique_janeiro_2016_relatorio_basico.pdf (dostęp: 16.08.2016 r.).

${ }^{5}$ Zob. pkt 8, 16 i 17 preambuły dyrektywy dystrybucyjnej. Warto zauważyć, iż w branży ubezpieczeniowej już pojawiają się głosy sugerujące, iż ciągłe poszerzanie katalogu obowiązków strony świadczącej profesjonalne usługi niekoniecznie jest dobre tak dla rynku oraz samego konsumenta. Konsumeryzm nie może stanowić głównego elementu kształtowania rzeczywistości gospodarczej, gdyż ostatecznie prowadzi do pogorszenia - podobnie jak socjalizm dla robotników - ich sytuacji (Ł. Zoń, Konsument - tak, konsumeryzm - nie, „Gazeta Ubezpieczeniowa” maj 2014, nr 21, s. 2).

${ }^{6}$ Przykład na poparcie tego stwierdzenia na gruncie prawa ubezpieczeniowego sensu largo stanowić może Dyrektywa Parlamentu Europejskiego i Rady 2009/138/WE $z$ dnia 25 listopada w sprawie podejmowania i prowadzenia działalności ubezpieczeniowej i reasekuracyjnej (Wypłacalność II), (Dz.Urz. UE L 335 z 17.12.2009). W jej kontekście za dyskusyjny należy uznać fakt, czy implementacja tej dyrektywy znacząco poprawiła pozycję konsumenta, zwłaszcza że odnotowano większą niż przed rokiem liczbę skarg i reklamacji w związku ze świadczeniem usług ubezpieczeniowych (por. Rzecznik Finansowy, Sprawozdanie Rzecznika Finansowego za 2015 r., Warszawa 2016). 
unijnym. Chociaż pojęcie „konsument” nie zostało zdefiniowane w dyrektywie dystrybucyjnej, to w preambule pojawia się ono aż kilkanaście razy. Jednocześnie zauważono, iż przyjęte rozwiązanie może wynikać $z$ charakteru dyrektywy obligującej państwa członkowskie do dokonania harmonizacji minimalnej (pkt 3 preambuły tego aktu). Dlatego państwa te są zobowiązanie w procesie implementacji przede wszystkim do urzeczywistnienia celów tak skonstruowanych dyrektyw przy jednoczesnej możliwości przyznania konsumentom korzystniejszych instrumentów ochronnych ${ }^{7}$.

Doniosłość dyrektywy dystrybucyjnej wynika ponadto $z$ faktu, zgodnie $z$ którym regulacje dotyczące pośrednictwa i dystrybucji ubezpieczeń - głównie ze względów historycznych i kulturowych różnią się znacznie w poszczególnych państwach członkowskich ${ }^{8}$. Dlatego zakres dyrektywy ${ }^{9}$ obejmuje każdą formę sprzedaży produktów ubezpieczeniowych (np. poprzez pośredników czy bezpośrednio przez zakłady ubezpieczeń), a nakładane na podmioty dystrybuujące wymogi mają charakter proporcjonalny. Ponadto akt wprowadza regulacje dotyczące m.in. zapobiegania ewentualnym konfliktom interesów, szczególnych warunków związanych ze sprzedażą krzyżową ${ }^{10}$, zwiększenia przydatności i obiektywności doradztwa ubezpieczeniowego, obowiązku ujawnienia przed zawarciem umowy charakteru i podstawy (nie kwoty) wynagrodzenia pośrednika ubezpieczeniowego, jak również zapewnienia, iż sprzedawca ubezpieczenia posiada odpowiednią znajomość produktu. Wreszcie dyrektywa wzmacnia skuteczność sankcji administracyjnych znajdujących zastosowanie w przypadku nieprzestrzegania określonych

7 B. Gnela, Ochrona konsumenta ustug finansowych. Wybrane zagadnienia prawne, Warszawa 2007, s. 52.

8 The European Federation of Insurance Intermediaries, BIPAR views on the revision of the IMD, s. 2, https://www.wko.at/Content.Node/branchen/t/sparte_ iuc/Versicherungsmakler-und-Berater-in-Versicherungsangelegenheiten/ BIPAR_views_on_the_IMD-revision_Oct2011_4.pdf (dostęp: 10.07.2016 r.).

${ }_{9}$ Zob. Better Regulation, Insurance Distribution Directive (IDD), http://www. betterregulation.com/ie/hot-topic/imd2 (dostęp: 10.07.2016 r.).

${ }^{10}$ Por. art. 24 dyrektywy dystrybucyjnej. Są to m.in. sytuacje, w których produkt ubezpieczeniowy oferowany jest wraz $z$ produktem uzupełniającym lub usługą uzupełniającą, które nie są ubezpieczeniem, jak część pakietu lub tej samej umowy. 
norm prawnych oraz podkreśla konieczność wzajemnego uznawania przez państwa członkowskie wiedzy i umiejętności pośredników w celu zwiększenia obrotu transgranicznego.

\subsection{Dyrektywa dystrybucyjna}

a dyrektywa o pośrednictwie ubezpieczeniowym

Dyrektywa dystrybucyjna stanowi największą - od ponad 14 lat zmianę prawodawstwa europejskiego, która wywiera bezpośredni wpływ na kwestie dotyczące pośrednictwa ubezpieczeniowego ${ }^{11}$. Przedmiotowe zagadnienia są obecnie uregulowane przez Dyrektywę 2002/92/WE Parlamentu Europejskiego i Rady z dnia 9 grudnia 2002 r. w sprawie pośrednictwa ubezpieczeniowego (ang. Insurance Mediation Directive) ${ }^{12}$. Została ona wdrożona do polskiego porządku prawnego na mocy ustawy $z$ dnia 22 maja 2003 r. o pośrednictwie ubezpieczeniowym ${ }^{13}$.

Stosunek zachodzący pomiędzy obiema dyrektywami kształtuje się w ten sposób, iż dyrektywa dystrybucyjna, czerpiąc $z$ doświadczeń pierwowzoru, a jednocześnie wprowadzając nowe, szeroko konsultowane rozwiązania, stanowi kolejny krok w celu integracji pośrednictwa ubezpieczeniowego i zapewnienia, podkreślonej wcześniej, efektywnej ochrony konsumentów w krajach Unii Europejskiej. W pkt 1 preambuły dyrektywy dystrybucyjnej zawarto postulat dotyczący konieczności wprowadzenia szeregu zmian, a ostatecznie przekształcenia pierwotnej regulacji. Asumpt do zwiększenia ochrony konsumentów dały przede wszystkim obecne i niedawne zaburzenia na rynkach finansowych oraz zbyt mały zdaniem europejskiego prawodawcy - poziom ochrony konsumentów. Przejawia się on chociażby potrzebą stosowania zróżnicowanych

${ }^{11}$ P. Piątkowski, „Broker w świetle Insurance Distribution Directive”, praca magisterska napisana pod kierunkiem prof. dr. hab. E. Kowalewskiego, Toruń 2016, s. 30.

12 Dz.Urz. WE L 9 z 15.01.2003 r., dalej: dyrektywa o pośrednictwie ubezpieczeniowym.

13 Tekst jedn. Dz.U. z 2014 r. Poz. 1450 ze zm., dalej: ustawa o pośrednictwie ubezpieczeniowym. 
środków krajowych (pkt 10 preambuły), co nie zawsze prowadzi do pożądanych $z$ punku widzenia ochrony konsumenta rezultatów.

Ostatecznie dyrektywa o pośrednictwie ubezpieczeniowym utraci moc 23 lutego 2018 r., tj. 24 miesiące po wejściu w życie dyrektywy dystrybucyjnej (art. 44 nowego aktu), ergo w momencie, gdy minie czas dostosowań prawodawstw państw członkowskich do nowych rozwiązań. Jednocześnie - zgodnie $z$ pkt 75 preambuły dyrektywy dystrybucyjnej, obowiązek jej transpozycji do prawa krajowego jest ograniczony wyłącznie do przepisów stanowiących merytoryczną zmianę dyrektywy o pośrednictwie ubezpieczeniowym. Z kolei obowiązek transpozycji przepisów, które nie uległy zmianie, nadal wynika ze starszej z dyrektyw.

Wreszcie na mocy art. 43 dyrektywy dystrybucyjnej od dnia 23 lutego 2016 r., uchylono obowiązywanie Rozdziału IIIA (,Dodatkowe wymogi w zakresie ochrony klientów dotyczące produktów inwestycyjnych opartych na ubezpieczeniu") dyrektywy o pośrednictwie ubezpieczeniowym.

\subsection{Dyrektywa jako źródło prawa Unii Europejskiej - wybrane kwestie}

Dyrektywa należy do wtórnych źródeł prawa Unii Europejskiej. Zgodnie $z$ art. 288 Traktatu o funkcjonowaniu Unii Europejskiej ${ }^{14}$ wiąże ona każde państwo, do którego jest kierowana, w zakresie rezultatu, który ma być osiągnięty. Pozostawia przy tym organom krajowym swobodę wyboru formy i środków implementacji.

Pojęcie implementacji, choć najprościej definiuje się je jako skuteczne wprowadzenie w życie aktu prawnego ${ }^{15}$, to w bardziej szczegółowej postaci obejmuje szereg działań właściwych organów krajowych prowadzących do skutecznego stosowania norm unijnych

${ }^{14}$ Dz.Urz. UE C 326 z 26.10.2012 r.

${ }^{15}$ C. Mik, Metodologia implementacji europejskiego prawa wspólnotowego $w$ krajowych porzadkach prawnych, w: Implementacja prawa integracji europejskiej $w$ krajowych porządkach prawnych, red. C. Mik, Toruń 1998, s. 28-29. 
(niejako modyfikowania prawa krajowego zgodnie $z$ prawem Unii ${ }^{16}$ ). W literaturze przedmiotu podnosi się, iż na całokształt implementacji składają się implementacja normatywna, administracyjna i sądowa ${ }^{17}$.

Z uwagi na fakt, zgodnie $z$ którym państwom Unii Europejskiej pozostawiono swobodę wyboru sposobu uwzględnienia treści dyrektywy w prawie krajowym, jej implementacja nie musi implikować konieczności uchwalenia nowego aktu prawnego. Natomiast państwa te są zobowiązane do „wyboru [...] najbardziej odpowiednich form i sposobów dla zapewnienia praktycznej skuteczności Dyrektyw, przy uwzględnieniu ich celów" ${ }^{18}$. W rezultacie dyrektywa wiąże państwa członkowskie w zakresie osiągnięcia konkretnych celów, a władze tych państw mają swobodę wyboru środków i form ich realizacji. Przedmiotowe akty służą harmonizacji, koordynacji oraz konwergencji prawodawstwa tych państw ${ }^{19}$. Dlatego w sytuacji osiągnięcia celów dyrektywy za pomocą odpowiednich działań legislacyjnych można mówić o spełnieniu wymogów prawa Unii Europejskiej w przewidzianym dyrektywą zakresie.

\section{Zakres przedmiotowy i podmiotowy stosowania dyrektywy}

Zgodnie $\mathrm{z}$ art. 1 pkt 1 dyrektywy dystrybucyjnej ustanawia ona zasady podejmowania i prowadzenia działalności ubezpieczeniowej w zakresie dystrybucji produktów ubezpieczeń i reasekuracji.

${ }^{16}$ Zob. E. Galewska, Implementacja dyrektyw telekomunikacyjnych, Kraków 2007, s. 56 wraz z cytowaną tam literaturą.

17 K. Kubuj, Implementacja prawa wspólnotowego na tle doświadczeń Francji, Warszawa 2006, s. 26-27. W przedmiocie szerokiego ujęcia procesu implementacji zob. także wyrok Trybunału Sprawiedliwości z dnia 19 listopada $1991 \mathrm{r}$. w połączonych sprawach 6/90 i 9/90 Andrea Francovich i Danila Bonifaci i in. v. Republica Italiana, http://curia.europa.eu/arrets/TRA-DOC-PL-ARRET-C0006-1990-200407021-05_00.html (dostęp: 10.07.2016 r.).

${ }^{18}$ Wyrok Trybunału Sprawiedliwości UE $z$ dnia 8 kwietnia 1976 r. w sprawie nr 48/75 Jean Noël Royer, Zbiór Orzecznictwa TS 1976, s. 497.

19 J. Galster, w: Podstawy prawa Unii Europejskiej z uwzględnieniem Traktatu z Lizbony, red. J. Galster, Toruń 2010, s. 328. 
Omawiany akt znajduje zastosowanie do każdej osoby fizycznej lub prawnej, zamieszkałej lub mającej siedzibę w państwie członkowskim, której działalność polega na świadczeniu usług dystrybucji ubezpieczeń lub reasekuracji na rzecz osób trzecich w Unii ${ }^{20}$.

Wyłączenia stosowania tego aktu zostały zawarte w art. 1 ust. 3 i dotyczą pośredników oferujących ubezpieczenia uzupełniające i wykonujących działalność z zakresu dystrybucji produktów ubezpieczeniowych, w przypadku gdy spełnione są łącznie następujące warunki:

a) ubezpieczenie obejmuje towar lub usługę dostarczaną przez dostawcę, w przypadku gdy takie ubezpieczenie obejmuje:

- ryzyko zniszczenia, utraty lub uszkodzenia towaru dostarczonego przez tego dostawcę lub nieskorzystania ze świadczonej przez niego usługi;

- uszkodzenie lub utratę bagażu i inne rodzaje ryzyka związanego z podróżą zarezerwowaną u tego dostawcy;

b) kwota składki $z$ tytułu umowy ubezpieczenia nie przekracza 600 EUR, obliczanej proporcjonalnie w wymiarze rocznym;

c) w drodze odstępstwa od lit. b), w przypadku gdy ubezpieczenie uzupełnia usługę, o której mowa w lit a), a czas trwania tej usługi nie przekracza trzech miesięcy, kwota składki płaconej od osoby nie przekracza 200 EUR.

Dystrybutorem ubezpieczeń - zgodnie $z$ art. 2 ust. 1 pkt 8 analizowanego aktu - jest każdy pośrednik ubezpieczeniowy, pośrednik oferujący ubezpieczenia uzupełniające lub zakład ubezpieczeń. Pod pojęciem pośrednika ubezpieczeniowego należy rozumieć każdą osobę fizyczną lub prawną, inną niż zakład ubezpieczeń lub reasekuracji lub ich pracownicy i inną niż pośrednik oferujący ubezpieczenia uzupełniające, która podejmuje lub prowadzi działalność z zakresu dystrybucji ubezpieczeń za wynagrodzeniem (art. 2 ust. 1 pkt 3 dyrektywy dystrybucyjnej).

Z kolei zakres stosowania starszej $z$ dyrektyw odnosi się wyłącznie do osób, których działalność polega na świadczeniu usług pośrednictwa ubezpieczeniowego na rzecz osób trzecich za wyna-

${ }^{20}$ Zob. pkt 11 preambuły dyrektywy dystrybucyjnej oraz art. 1 ust. 2 tego aktu. 
grodzeniem (pkt 11 preambuły dyrektywy o pośrednictwie ubezpieczeniowym). Jak widać, zmiana zakresu podmiotowego polega na jego rozszerzeniu $z$ pośrednictwa na dystrybucję. Relacja tych pojęć kształtuje się w ten sposób, że każde pośrednictwo jest dystrybucją, ale nie każda dystrybucja stanowi pośrednictwo. W rezultacie poza materią wspólną dotyczącą klasycznie pojmowanego pośrednictwa ubezpieczeniowego termin „dystrybucja” odnosi się również do zakładów ubezpieczeńn ${ }^{21}$, a ponadto wyodrębnia grupę podmiotów prowadzących działalność ubezpieczeniową określaną jako uzupełniająca, do których zalicza się biura podróży czy wypożyczalnie samochodów ${ }^{22}$. Zestawiając to $\mathrm{z}$ regulacjami polskimi, warto podkreślić, iż dystrybucję ubezpieczeń mogą prowadzić różne rodzaje osób lub instytucji, w tym wymienieni expressis verbis brokerzy i agenci ubezpieczeniowi czy podmioty oferujące produkty ubezpieczeniowe klientom banków (art. 5 preambuły dyrektywy dystrybucyjnej).

Samo pojęcie dystrybucji ubezpieczeń zostało opisane w art. 2 ust. 1 pkt 1 przedmiotowej dyrektywy i oznacza działalność polegającą na doradzaniu, proponowaniu lub przeprowadzaniu innych prac przygotowawczych do zawarcia umów ubezpieczenia, na zawieraniu takich umów lub udzielaniu pomocy w administrowaniu takimi umowami i wykonywaniu ich, w szczególności w przypadku roszczenia, w tym udzielaniu informacji dotyczących jednej lub większej liczby umów ubezpieczenia na podstawie kryteriów wybranych przez klienta za pośrednictwem stron internetowych lub innych mediów. Ponadto, na mocy powyższej normy, definiowany

${ }^{21}$ Zob. art. 2 ust. 1 pkt 7 dyrektywy dystrybucyjnej. Przyjęte rozwiązanie nie cieszy się powszechną akceptacją w doktrynie przedmiotu. Wskazuje się, iż objęcie regulacjami dotyczącymi pośrednictwa ubezpieczeniowego czegoś, co nie jest pośrednictwem, należy uznać za zabieg sztuczny, zniekształcający ustawowy model pośrednictwa i prowadzący do rozmycia sensu tego pojęcia i celu jego regulacji (J. Pokrzywniak, Ustawa o pośrednictwie ubezpieczeniowym - ocena $i$ uwagi „de lege ferenda” $w$ kontekście prac nad nowelizacją dyrektywy $w$ sprawie pośrednictwa ubezpieczeniowego, w: Ubezpieczenia gospodarcze. Wybrane zagadnienia prawne, red. B. Gnela, Warszawa 2011, s. 206).

${ }^{22}$ Zob. art. 2 ust. 1 pkt 4 dyrektywy dystrybucyjnej oraz pkt 8 preambuły tego aktu. 
termin obejmuje również działania związane $\mathrm{z}$ opracowywaniem rankingów produktów ubezpieczeniowych obejmujących porównanie cen i produktów czy udzielanie zniżki od ceny umowy ubezpieczenia, gdy klient jest w stanie pośrednio lub bezpośrednio zawrzeć umowę ubezpieczenia za pośrednictwem stron internetowych lub innych mediów. W tym kontekście warto podkreślić, iż w obrębie dystrybucji ubezpieczeń została unormowana problematyka tzw. kanałów direct $^{23}$, jako metody sprzedaży produktów ubezpieczeniowych.

W przypadku dyrektywy dystrybucyjnej należy stwierdzić, iż wprowadza ona zasadę level playing field ${ }^{24}$, która polega na jednakowym traktowaniu objętych jej zakresem podmiotów gospodarczych, niezależnie od kanałów dystrybucji (pkt 6 preambuły). Takie zrównanie obowiązków dystrybutora ubezpieczeń i postawienie wysokich wymogów formalnych nie zawsze wydaje się słuszne. W przypadku małych podmiotów okazjonalnie świadczących usługi ubezpieczeniowe możemy mieć do czynienia albo $z$ rezygnacją $z$ nich, albo świadczeniem takich usług w szarej strefie ${ }^{25}$.

Ponadto wydaje się, iż dyrektywie dystrybucyjnej towarzyszy szczególna wątpliwość wynikająca $z$ objęcia jej zakresem zakładów ubezpieczeń. Przedmiotowy zarzut może być formułowany w kontekście zasady proporcjonalności i nałożenia na nie licznych obowiązków wynikających już z dyrektywy Wypłacalność II (m.in. w sferze informacyjnej, nadzorczej czy kapitałowej), która została implementowana do krajowego porządku prawnego na mocy Ustawy z dnia 11 września 2015 r. o działalności ubezpieczeniowej i reasekuracyjnej ${ }^{26}$. W efekcie wymogi stawiane zakładom ubezpieczeń

${ }^{23}$ Taki kanał dystrybucji ubezpieczeń polega na możliwości ich zakupu przez internet lub telefon, bez udziału agenta ubezpieczeniowego. W rezultacie składka ubezpieczenia jest niższa, a wśród innych zalet przedmiotowego rozwiązania podkreśla się jeszcze wygodę oraz szybkość zawarcia umowy. Szczególną rolę odgrywają w omawianym przypadku tzw. internetowe porównywarki ubezpieczeniowe (wirtualne multiagencje ubezpieczeniowe). Ich rola sprowadza się do zaprezentowania w oparciu o udzielone informacje ofert różnych zakładów ubezpieczeń i zakupu ubezpieczenia za pośrednictwem internetu.

${ }^{24}$ The Free Dictionary - level playing field, http://idioms.thefreedictionary. com/level+playing+field (dostęp: 10.07.2016 r.).

25 P. Piątkowski, op.cit., s. 39.

${ }^{26}$ Dz.U. z 2015 r. Poz. 1844. 
będą rozbudowane. Natomiast jeżeli będą one jednocześnie dystrybutorami, to liczba obowiązków informacyjnych, co będzie rozwinięte w dalszej części pracy, może stać w sprzeczności z koniecznością ich zwięzłości i zrozumiałości dla konsumenta.

Wreszcie warto podkreślić, iż istotne zbliżenie pozycji prawnej dystrybutorów i pośredników sensu stricto odstępuje od tradycyjnej struktury rynku ubezpieczeniowego i w rezultacie może osłabić status i rolę pośredników ubezpieczeniowych ${ }^{27}$.

\section{Zarys obowiązków informacyjnych na gruncie dyrektywy dystrybucyjnej}

Jak wspomniano wcześniej, dyrektywa dystrybucyjna istotnie poszerzyła zakres obowiązków informacyjnych, do których udzielania zobowiązani będą pośrednicy ubezpieczeniowi. Chociaż zgodnie z pkt 52 preambuły omawianego aktu przedmiotowy zakres ma charakter minimalny, to jest on jednak na tyle szczegółowy i rozbudowany, że dalsze jego powiększanie, na skutek indywidualnej decyzji państwa członkowskiego, nie wydaje się celowe. Już w trakcie prac nad dyrektywą środowiska pośredników ubezpieczeniowych podnosiły, iż tak obszerne zakreślenie obowiązków informacyjnych może skutecznie odwracać uwagę klientów od najistotniejszych kwestii związanych $z$ pośrednictwem ubezpieczeniowym i zawieraną umową, ergo wysokością składki i zakresem ubezpieczenia ${ }^{28}$.

Przechodząc do analizy poszczególnych obowiązków informacyjnych, należy zacząć od konieczności udzielenia danych o pośredniku (dystrybutorze) ubezpieczeniowym. Niektóre $z$ takich informacji wynikają już z dyrektywy o pośrednictwie ubezpieczeniowym i zostały implementowane do krajowego porządku prawnego w ustawie o pośrednictwie ubezpieczeniowym ${ }^{29}$. Na mocy nowej regulacji ów

27 P. Tereszkiewicz, Obowiazki informacyjne w umowach o usługi finansowe, Warszawa 2015.

${ }^{28}$ Kluczowe kwestie IMD 2, Dokument BIPAR, http://www.polbrokers.pl/ problemy_prawne (dostęp: 10.07.2016 r.).

${ }^{29}$ Zob. art. 26 tej ustawy. 
zakres został poszerzony m.in. o konieczność przekazania poszukującemu ochrony informacji o swoich danych adresowych, fakcie bycia pośrednikiem ubezpieczeniowym, rejestrze, do którego jest on wpisany, oraz możliwości weryfikacji tego faktu (art. 18 dyrektywy dystrybucyjnej) czy o charakterze i metodach ustalania wynagrodzenia (art. 19 tego aktu). Zgodnie $z$ pkt 40 preambuły dyrektywy dystrybucyjnej te informacje powinny być przekazane klientom przed zawarciem umowy.

Kolejny rodzaj obowiązków informacyjnych dotyczy konieczności przeprowadzenia analizy i wydania rekomendacji określonego produktu ubezpieczeniowego, jak również przekazania - przed zawarciem umowy ubezpieczenia - odrębnego dokumentu zawierającego informacje o takim produkcie. Zgodnie $z$ pkt 44 preambuły dyrektywy dystrybucyjnej, aby zapobiec przypadkom niewłaściwej sprzedaży produktów ubezpieczeniowych, należy każdorazowo przeprowadzić test wymagań i potrzeb klienta, a więc produkt musi odpowiadać jego potrzebom i być przedstawiony w zrozumiałej formie, która umożliwi mu podjęcie świadomej decyzji ${ }^{30}$.

Interesująco kształtuje się przede wszystkim obowiązek przekazania dokumentu $z$ informacjami o produkcie ubezpieczeniowym. Otóż zgodnie $z$ art. 20 ust. 7 dyrektywy dystrybucyjnej powinien być on m.in. krótki, przejrzysty, czytelny - także odnośnie do użytej czcionki, dokładny i niewprowadzający w błąd, należycie zatytułowany, jak również sporządzony w języku urzędowym państwa, w którym produkt ubezpieczeniowy jest oferowany, lub w innym, indywidualnie uzgodnionym pomiędzy dystrybutorem a klientem. Ponadto w dokumencie muszą znajdować się informacje o rodzaju ubezpieczenia, ochronie ubezpieczeniowej i głównych wyłączeniach, trybie uiszczania składki i okresach płatności, czasie trwania umowy, wynikających $z$ niej obowiązkach, jak również trybie rozwiązania umowy.

${ }^{30}$ Przedmiotowe rozwiązanie jest podobne do rozwiązania dotyczącego wymogów ankietowania ubezpieczającego, który chce zawrzeć umowę ubezpieczenia na życie $z$ ubezpieczeniowym funduszem kapitałowym lub ubezpieczenia na życie, w którym świadczenie zakładu ubezpieczeń jest ustalana w oparciu o określone indeksy lub inne wartości bazowe (zob. art. 21 ust. 1 ustawy o działalności ubezpieczeniowej i reasekuracyjnej). 
Wskazane wymogi co do zasady zawierają przedkontraktowe obowiązki ubezpieczyciela zawarte w rozdziałach 1 i 2 PEICL. Pewne różnice wynikające chociażby $\mathrm{z}$ obowiązków wskazania różnic między oczekiwaną a proponowaną treścią umowy (art. 2:202 PEICL) czy wskazania początku ochrony ubezpieczeniowej, jeżeli ubezpieczający pozostaje $\mathrm{w}$ uzasadnionym, lecz błędnym przekonaniu co do tej daty, a ubezpieczyciel wie tudzież powinien wiedzieć o tym przekonaniu (art. 2:203 PEICL), nie będą dotyczyły wszystkich stanów faktycznych. Ponadto istotnie „konsumują” się one w obrębie niektórych innych rozwiązań przewidzianych w dyrektywie dystrybucyjnej (m.in. w obowiązku przeprowadzenia testu wymagań i potrzeb klienta, w obowiązku informacyjnym nałożonym na pośrednika ubezpieczeniowego lub zakład ubezpieczeń czy w obowiązku działania $z$ najlepiej pojętym interesem swoich klientów).

W kontekście problematyki poruszonej w tej części pracy warto podnieść dwie kwestie. Pierwsza $z$ nich dotyczy korelacji pomiędzy przejrzystością i zwięzłością przedmiotowego dokumentu, a wynikającymi z dyrektywy obowiązkowymi informacjami, które muszą być w nim zawarte. Otóż w odniesieniu do niektórych, zwłaszcza bardziej wyszukanych produktów ubezpieczeniowych oba wymagania mogą wzajemnie się wykluczać ${ }^{31}$. Druga kwestia związana jest $z$ relacją tego dokumentu do nałożonego na zakłady ubezpieczeń (de facto pośredników) na mocy art. $384 \S 1$ k.c. ${ }^{32}$ obowiązku dostarczenia przed zawarciem umowy wzorca umownego, który stanowią ogólne warunki ubezpieczenia. $Z$ oczywistych względów ten ostatni jest bardziej szczegółowy i obszerny ${ }^{33}$. W konsekwencji tego należy zauważyć, iż pośrednik (dystrybutor) będzie zobowiązany do dostarczenia wielu dokumentów, których treść będzie się powielała, a to może skutecznie „zamazać” kluczowe kwestie dotyczące zawieranej umowy ubezpieczenia i doprowadzić do dezorientacji klienta. Co więcej, ze

31 P. Piątkowski, op.cit., s. 45.

${ }^{32}$ Ustawa z dnia 23 kwietnia 1964 r. - Kodeks cywilny, tekst jednolity: Dz.U. z 2014 r., poz. 121 ze zm., dalej: k.c.

${ }^{33}$ Zob. art. 15-17 ustawy o działalności ubezpieczeniowej i reasekuracyjnej. Należy jednak pamiętać, iż ogólne warunki ubezpieczenia oraz inne wzorce umowy muszą być formułowane jednoznacznie i w sposób zrozumiały (art. 15 ust. 3 tego aktu). 
względu na liczbę przekazywanych dokumentów należy liczyć się z tym, iż klient w ogólne nie zechce się z nimi zapoznać. Wreszcie warty podkreślenia jest fakt, iż klienci wybierają pośredników przede wszystkim $z$ uwagi na ich profesjonalizm i dostosowywanie produktu ubezpieczeniowego do konkretnych wymagań, polegając niekiedy wyłącznie na informacjach i zapewnieniach uzyskanych podczas rozmowy i zawierania umowy.

Następna grupa obowiązków informacyjnych dotyczy konieczności przedstawienia klientom i innym zainteresowanym podmiotom zasad składnia skarg na pośredników ubezpieczeniowych, jak również wskazania dostępnych procedur reklamacyjnych i odszkodowawczych (art. 18 dyrektywy dystrybucyjnej). Zgodnie z pkt 38 preambuły omawianej dyrektywy celem powyższych procedur jest szybsze i mniej kosztowne rozstrzyganie sporów pomiędzy dystrybutorami a klientami w przedmiocie praw i obowiązków wynikających $z$ tego aktu. Jednocześnie dyrektywa silnie akcentuje, co będzie ważne w kontekście dalszych rozważań, iż w stosownych przypadkach należy korzystać z procedur już istniejących.

W obowiązującym stanie prawnym istnieje możliwość składania skarg wewnętrznych na pracowników pośredników ubezpieczeniowych (np. do osób bezpośrednio przełożonych) lub zewnętrznych. Te ostatnie należy kierować w przypadku brokera ubezpieczeniowego do organu odpowiedzialnego za nadzór (Komisja Nadzoru Finansowego), a w przypadku agenta ubezpieczeniowego do zakładu ubezpieczeń, na rzecz którego agent prowadzi czynności agencyjne. Trudności, zwłaszcza w kontekście Ustawy z dnia 5 sierpnia 2015 r. o składaniu reklamacji przez podmioty rynku finansowego i o Rzeczniku Finansowym ${ }^{34}$, budzi kwestia składania reklamacji. Otóż wskazana ustawa pozwala na kierowanie ich do podmiotów rynku finansowego (m.in. krajowych i zagranicznych zakładów ubezpieczeń). Pojęcie reklamacji - zgodnie $z$ art. 2 pkt 2 tego aktu jest definiowane jako wystąpienie skierowane do podmiotu rynku finansowego przez jego klienta, w którym klient zgłasza zastrzeżenia dotyczące usług świadczonych przez podmiot rynku finansowego. $\mathrm{W}$ oparciu o to należy sformułować dwie uwagi. Pierwsza dotyczy

${ }^{34}$ Dz.U. z 2015 r., poz. 1348, dalej: ustawa reklamacyjna. 
faktu, iż klasycznie pojmowane pośrednictwo ubezpieczeniowe jest wyłączone z zakresu unormowań ustawy reklamacyjnej, gdyż dotyczy ona wyłącznie relacji klient-zakład ubezpieczeń. Druga uwaga wynika z lapidarnej, ergo bardzo szerokiej i sprawiającej trudności interpretacyjne, legalnej definicji reklamacji ${ }^{35}$. Wskazany stan każe przyjąć, iż w kwestii przedmiotowej ta ustawa częściowo czyni zadość wymogom stawianym przez dyrektywę dystrybucyjną, obejmując swym zakresem ten element dystrybucji ubezpieczeń, w którym udział biorą wyłącznie klient ${ }^{36}$ i zakład ubezpieczeń (primo zakup produktu ubezpieczeniowego bezpośrednio od zakładu ubezpieczeń, co jednak nie odgrywa znaczącej roli na rynku krajowym).

Reasumując przeprowadzoną analizę, należy stwierdzić, że ustawa reklamacyjna, choć uchwalona w chwili, gdy kończono prace nad kształtem dyrektywy dystrybucyjnej, nie będzie zapewniała pełni jej skuteczności w kontekście wymagań wskazanych w art. 14 i 15 dyrektywy dystrybucyjnej odnośnie do procedur dotyczących skarg, reklamacji i odszkodowań. W rezultacie konieczne będzie podjęcie właściwych działań zapewniających skuteczność prawa unijnego, zwłaszcza że istniejące, ogólne zasady prawa odszkodowawczego wydają się nie spełniać celów dyrektywy, jakimi są m.in. szybkość i niska cena, ergo dostępność takich procedur.

\section{Wybrane zagadnienia implementacji dyrektywy ubezpieczeniowej w kontekście działalności brokera ubezpieczeniowego}

Z punktu widzenia prawa krajowego do szczególnie newralgicznych kwestii związanych z koniecznością implementacji dyrektywy

${ }^{35}$ Zob.: E. Kowalewski, M.P. Ziemiak, Ustawa reklamacyjna a obrót ubezpieczeniowy (część I), „Wiadomości Ubezpieczeniowe” 2015, nr 3, s. 34 i n.; P. Pawlak, M. Marszelewski, Ustawa reklamacyjna z perspektywy rynku ubezpieczeń gospodarczych, w: Państwo a gospodarka. Prawna regulacja podejmowania i prowadzenia działalności gospodarczej, red. H. Nowicki, P. Nowicki, Toruń 2016.

${ }^{36}$ Zgodnie $\mathrm{z}$ art. 2 pkt 1 ustawy reklamacyjnej klientem podmiotu rynku finansowego może być tylko osoba fizyczna, niezależnie od tego, czy jest ona 
dystrybucyjnej należy pytanie o przyszły kształt (model) pośrednictwa ubezpieczeniowego. Przedmiotowe zagadnienie jest szeroko komentowane w środowisku brokerskim ${ }^{37} \mathrm{z}$ uwagi na konieczność „pogodzenia” roli brokera działającego w imieniu lub na rzecz podmiotu poszukującego ochrony $z$ koncepcją dystrybucji ubezpieczeń. Przedmiotowa kwestia - prima facie - wydaje się budzić największe trudności w obliczu konieczności harmonizacji rozwiązań polskich z prawem europejskim.

Dyrektywa dystrybucyjna, jak wspomniano wcześniej, nie wyklucza udziału brokera w procesie dystrybucji ubezpieczeń. Choć termin „broker” został użyty jedynie dwa razy, to pkt 5 preambuły tego aktu explicite stanowi, iż brokerzy mogą zajmować się dystrybucją ubezpieczeń obok m.in. biur podróży czy wypożyczalni samochodowych. Dysonans zachodzący pomiędzy działalnością brokerów, którzy niejednokrotnie oprócz bardzo skomplikowanych kwestii stricte ubezpieczeniowych świadczą również inne usługi związane $z$ kompleksową obsługą klientów (zazwyczaj dużych przedsiębiorstw) m.in. w zakresie zarządzania ryzykiem, a innymi dystrybutorami ubezpieczeń zdaje się aż nadto widoczny, by nie powiedzieć krzyw$\mathrm{dzący}^{38}$. Jednocześnie nie ma żadnych innych zapisów regulujących wprost (bądź wprowadzających ewentualne odrębności) działalność brokerską. Te względy czynią zasadną konieczność podjęcia

konsumentem w świetle art. 221 k.c. Przedmiotowa teza wynika $z$ faktu, iż wykładnia tej normy ustawy reklamacyjnej nie wprowadza kryterium różnicującego na osoby fizyczne wykonujące działalność gospodarczą lub zawodową lub osoby niewykonujące takiej działalności, ergo nie odsyła do wskazanej normy k.c.

37 Przykład może stanowić konferencja naukowa pt. „O nowy kształt pośrednictwa ubezpieczeniowego" zorganizowana 27 października 2015 r. w Warszawie przez Szkołę Główną Handlową.

${ }^{38}$ Brokerzy istnieją na krajowym rynku ubezpieczeniowym od ponad 25 lat. W tym czasie nie tylko stali się jego nieodłączną częścią, ale zyskali również powszechną rozpoznawalność czy zaufanie ze strony swoich klientów. W przypadku brokerów coraz częściej mówi się o zawodzie, a nie jedynie o wykonywaniu działalności gospodarczej. Konsekwencje likwidacji czy znaczącej zmiany charakteru działalności brokerskiej byłyby bardzo groźne dla skądinąd - dobre funkcjonującej branży pośrednictwa ubezpieczeniowego. Co więcej, nawet w sytuacji zmiany prawnych uwarunkowań ich działalności, najprawdopodobniej i tak - w postaci czynności faktycznych - prowadziliby zbliżoną do obecnej działalność. 
próby niejako „wkomponowania” brokera w proces dystrybucji ubezpieczeń.

Regulacja krajowa w miejsce przedmiotowej definicji pośrednictwa ubezpieczeniowego zawartej w dyrektywie z 2002 r. wprowadza podział podmiotowy na brokerów, agentów (multiagentów) oraz osoby wykonujące czynności agencyjne. Wskazane podmioty jako jedyne mogą wykonywać czynności pośrednictwa ubezpieczeniowego ${ }^{39}$. Implementacja dyrektywy dystrybucyjnej $-z$ natury rzeczy - wpłynie na te rozwiązania, wymuszając ich daleko idące modyfikacje, a w skrajnym przypadku, przy dostatecznej woli ustawodawcy, zupełnie nowe rozwiązania.

Jedną z najłatwiejszych do dostrzeżenia kwestii jest nieadekwatność pojęcia „dystrybutor” do statusu brokera ubezpieczeniowego. Przedmiotowy termin oznacza osobę bądź instytucję zajmującą się dystrybucją towarów ${ }^{40}$ lub osobę tudzież instytucję mającą prawo do kupowania, sprzedaży i rozprowadzania na danym terenie towarów wyprodukowanych przez inne podmioty ${ }^{41}$. Osoba dystrybutora związana więc jest bezpośrednio $z$ towarem (nie usługą), co ważne, wyprodukowanym przez inne podmioty. Odnosząc to na grunt definicji brokera ubezpieczeniowego, należy stwierdzić, iż omawiany termin jest całkowicie niedostosowany do specyfiki zawodu brokera. Po pierwsze, oferuje on usługę, nie towar ${ }^{42}$, a po drugie, broker nie „rozprowadza” towaru wyprodukowanego wyłącznie przez inny podmiot (tu zakład ubezpieczeń) ${ }^{43}$.

${ }^{39}$ Ł. Zoń, Refleksje prawnika i brokera nad nowa europejska dyrektywa o pośrednictwie ubezpieczeniowym, http://www.eib.com.pl/uploads/news/ lukasz\%20zon\%20o\%20imd2.pdf (dostęp: 10.07.2016 r.); por. także B. Wojno, Przedmiotowy zakres pośrednictwa ubezpieczeniowego, w: Ubezpieczenia gospodarcze, s. 213 i n.

40 B. Dunaj, Nowy słownik języka polskiego, Warszawa 2005, s. 116.

${ }^{41}$ Encyklopedia Zarządzania - „dystrybutor”, https://mfiles.pl/pl/index. php/Dystrybutor (dostęp: 10.07.2016 r.).

${ }^{42}$ Por. Polska Klasyfikacja Działalności, grupa 66.22.Z - Działalność agentów i brokerów ubezpieczeniowych (działalność kwalifikowana jako usługa).

${ }^{43}$ Broker tworzy nowe programy ubezpieczeniowe, identyfikuje ewentualne zagrożenia płynące $z$ bezpośredniej implementacji warunków pakietowych czy kreuje warunki umowy ubezpieczenia wraz z opracowanymi, własnymi klauzulami brokerskimi. 
Przechodząc na grunt konkretnych wymagań stawianych pośrednikom ubezpieczeniowym przez dyrektywę dystrybucyjną, trzeba podnieść, iż brokerzy spełniają zawarte w art. 10 ust. 4 i 5 wymogi odnośnie do obowiązkowego ubezpieczenia odpowiedzialności cywilnej. Kolejna kwestia dotyczy uregulowanego w art. 10 ust. 2 tego aktu szkolenia lub doskonalenia zawodowego w wymiarze co najmniej 15 godzin rocznie. Zestawiając ten obowiązek $z$ regulacją kształcenia zawodowego brokera ubezpieczeniowego, konieczne jest poczynienie odwołania do tzw. ustawy deregulacyjnej ${ }^{44}$. Zgodnie $\mathrm{z}$ art. 10 ust. 1 przedmiotowego aktu zniesiono wymóg doskonalenia umiejętności zawodowych polegający na odbywaniu szkolenia zawodowego raz na trzy lata. W tym kontekście można wspomnieć, iż istnienie uchylonego art. 4c ustawy o pośrednictwie ubezpieczeniowym dotyczącego wskazanego obowiązku wynikało m.in. dyrektywy o pośrednictwie ubezpieczeniowym. Ostatecznie konieczność odbywania wspomnianych szkoleń została zastąpiona wymogiem uczestnictwa w szkoleniach cyklicznych ${ }^{45}$. Mając to na względzie, trzeba stwierdzić, że implementacja art. 10 ust. 2 dyrektywy dystrybucyjnej do prawa krajowego wydaje się stosunkowo łatwa. Analizowany wymóg, co wielokrotnie podkreślano, spotyka się z aprobatą Stowarzyszenia Polskich Brokerów Ubezpieczeniowych i Reasekuracyjnych, które podkreśla konieczność przygotowania szkoleń zapewniających możliwie największą efektywność zarówno w odniesieniu do konkretnego podmiotu dystrybuującego ubezpieczenia, jak i oferowanych przez niego produktów.

Kolejne wymogi stanowią wspomniane wcześniej obowiązki informacyjne (art. 17-19 dyrektywy dystrybucyjnej) czy obowiązki związane $z$ ochroną klientów przed niezdolnością pośrednika do przekazania składki (art. 10 ust. 6 omawianego aktu). W kontekście tych ostatnich warto zauważyć, iż dotychczasowy model ochrony klienta przed niezdolnością pośrednika do przekazania składki lub świadczenia kształtuje się w sposób, zgodnie z którym

${ }^{44}$ Ustawa $z$ dnia 9 maja 2014 r. o ułatwieniu dostępu do wykonywania niektórych zawodów regulowanych, tekst jedn. Dz.U. z 2014 r. Poz. 768.

45 Zob. Ł. Zoń, Deregulacja zawodu brokera ubezpieczeniowego i reasekuracyjnego, „Prawo Asekuracyjne” 2014, nr 3, s. 95 i n. 
sumy pieniędzy wpłacone pośrednikowi przez klienta traktuje się jako wpłacone zakładowi. $Z$ kolei środki wypłacone przez zakład ubezpieczeń pośrednikowi traktuje się jako wypłacone klientowi dopiero w chwili, gdy faktycznie je otrzyma. Istniejące rozwiązanie, przenosząc na brokera odpowiedzialność za przekazanie otrzymanej od klienta składki, wydaje się czynić zadość wymogom dyrektywy. W jego świetle wystarczy, iż klient udowodni fakt przekazania kwoty składki brokerowi. Ewentualne „wzmocnienie” pozycji klienta mogłyby zagwarantować regulacje wprowadzające odpowiedni wzór pokwitowania przyjęcia składki i obligatoryjność każdorazowego wydania takiego dokumentu (należy jednak mieć na względzie, iż takie pokwitowania są co do zasady wystawiane). Jednocześnie warto pamiętać, iż udział brokera ubezpieczeniowego jest często związany $z$ istnieniem dużego ryzyka ubezpieczeniowego, co implikuje wysoką składkę ubezpieczeniową. Takie kwoty bardzo rzadko są przekazywane $\mathrm{w}$ formie gotówki, zdecydowanie częściej ma miejsce przelew środków na określone konto bankowe, co per se wiąże się $z$ istnieniem potwierdzeń przedmiotowych działań.

Wreszcie warto zwrócić uwagę na regulacje zapobiegające powstaniu konfliktu interesów w działalności pośredników ubezpieczeniowych (art. 17, 22 ust. 3, 27 i 28 dyrektywy dystrybucyjnej). Implementacja powyższych norm nie wydaje się ani szczególnie skomplikowana, ani tym bardziej niemożliwa do „włączenia” w zakres działalności brokerskiej, zwłaszcza w kontekście unormowania powiązania konfliktów interesu $z$ wynagrodzeniem. Przykład na istnienie zarysu takich rozwiązań w odniesieniu do ubezpieczenia na cudzy rachunek stanowić może art. 18 ustawy o działalności ubezpieczeniowej i reasekuracyjnej. W tym miejscu należy podkreślić zasadność równorzędności uregulowania przedmiotowej kwestii w odniesieniu do każdego dystrybutora ubezpieczeń (zakładów ubezpieczeń i pośredników), gdyż w innym przypadku nie będziemy mieli do czynienia $z$ równowagą konkurencyjną pomiędzy tymi podmiotami. Idąc dalej, w kontekście ewentualnych konfliktów interesów nie można zapominać o fundamentalnej zasadzie oparcia umowy ubezpieczenia na dobrej wierze, jako podstawie kreowania rynku ubezpieczeniowego. Zasada ta - zdaniem Katarzyny Malinowskiej - staje się niestety zastępowana szeregiem nakazów i zakazów, 
a przede wszystkim zasadą transparentności, która coraz częściej substytuuje dobrą wiarę w relacjach kontraktowych ${ }^{46}$.

Charakteryzując problematykę unijnej regulacji konfliktu interesów, nie sposób pominąć stosowanych na rynku zasad poufności - tzw. barier informacyjnych, znanych również jako „chiński mur". Ta metoda stosowana jest w przypadku współpracy podmiotu świadczącego usługi dla dwóch konkurencyjnych przedsiębiorstw usługodawca najczęściej za zgodą konkurencyjnych usługobiorców deleguje do obsługi dwa oddzielne zespoły pracowników i zapewnia całkowitą poufność. Niniejsze rozwiązanie, zaczerpnięte nota bene z wniosków prac Zespołu ds. Etyki przy Polskim Związku Pracodawców Prawniczych, może stać się niezwykle pomocną wytyczną przy prawidłowej implementacji dyrektywy dystrybucyjnej w zakresie zapobiegania konfliktom interesów występujących wśród pośredników ubezpieczeniowych. Jak wskazano we wnioskach Zespołu ds. Etyki, podstawową zasadą w przypadku świadczenia usług na rzecz kilku usługobiorców jest ich zgoda na przedmiotowe działanie. Kwestię wtórną stanowi świadczenie usług pośrednictwa przez jeden podmiot - wówczas wytyczną pozostaje zastosowanie się do zasady maksymalnego obiektywizmu działania, zaś w przypadku świadczenia usług przez różne zespoły - przestrzeganie zasady poufności (brak dostępu do informacji, które pozyskał dany zespół przez członków odrębnego zespołu) ${ }^{47}$.

Zaprezentowana - mimo wszystko pobieżna - analiza pozwala wysunąć uzasadniony postulat o minimalnym charakterze implementacji dyrektywy dystrybucyjnej w odniesieniu do działalności brokerskiej. Zachowanie obecnego modelu regulacji takiej działalności oraz uwzględnienie obowiązków wynikających z przedmiotowej dyrektywy stanowi zdaniem autorów najlepsze i w zasadzie jedyne

${ }^{46}$ K. Malinowska, Konflikt interesów $w$ działalności brokerskiej $w$ świetle obowiazującego prawa i tendencji europejskich, w: Konkurencja i konkurencyjność na rynku ubezpieczeniowym, red. M. Serwach, Warszawa 2015, s. 161.

47 Polski Związek Pracodawców Prawniczych, Wnioski z prac Zespołu ds. Etyki przy Polskim Związku Pracodawców Prawniczych, s. 2, http://www.pracodawcyprawniczy.org.pl/dokumenty.html (dostęp: 16.08.2016 r.). 
pożądane rozwiązanie, które przyczyni się do dalszego rozwoju działalności brokerskiej w kraju ${ }^{48}$.

\section{Wnioski}

Dyrektywa dystrybucyjna stanowi ważny krok w kierunku ujednolicenia rynku sprzedaży ubezpieczeń w Unii Europejskiej. Różnorodność postaci przedmiotowych działań w poszczególnych krajach wymusiła konieczność odwołania do możliwie najszerszego pojęcia, jakim jest dystrybucja ubezpieczeń. Ponadto omawiany akt wprowadza liczne rozwiązania wzmacniające zaufanie klientów do sektora ubezpieczeniowego.

W kontekście prawa polskiego należy stwierdzić, iż to, czy będziemy mieć do czynienia $z$ ewolucją czy rewolucją na rynku pośrednictwa ubezpieczeniowego, zależy od ustawodawcy. Dlatego należy apelować o działania, które w możliwie największym zakresie przyczynią się do utrzymania wytworzonego i dobrze funkcjonującego podmiotowego podziału pośredników ubezpieczeniowych wraz $\mathrm{z}$ jednoczesnym uwzględnieniem kolejnych przewidzianych dyrektywą kanałów sprzedaży ubezpieczeń (de facto niekiedy już istniejących, np. kanał direct). Natomiast próby ewentualnego zredefiniowania takiego podziału i sprowadzenia go do ogólnej kategorii dystrybutora, nie tylko nie wydają się zasadne $z$ punktu widzenia uzupełniających się zakresów działalności agentów i brokerów, ale skutkowałyby dezorientacją klientów i wymuszeniem zmiany, utrwalonego przez lata, modelu poruszania się po rynku usług ubezpieczeniowych, co w efekcie mogłoby stać w sprzeczności z prokonsumenckim charakterem dyrektywy dystrybucyjnej.

$Z$ kolei w odniesieniu do działalności brokerskiej jako wrażliwego obszaru implementacji omawianej dyrektywy należy podkreślić, iż niektóre zawarte w niej wymogi już funkcjonują w regulacji krajowej, a nowe - nie tylko prima facie - nie wydają się szczególnie trudne

48 Szerzej na temat postulowanych zmian w zakresie implementacji zapisów dyrektywy w odniesieniu do brokera ubezpieczeniowego zob. P. Piątkowski, op.cit., s. 50-62. 
czy też konfliktogenne w kontekście wprowadzania do prawa polskiego. Ponadto warto mieć zawsze na względzie całokształt usług oferowanych przez brokerów i ich rolę, która nie tylko wiąże się ze znalezieniem odpowiedniego ubezpieczenia dla swoich klientów, ale dotyczy również udzielania im szeroko rozumianej pomocy obejmującej czynności wykraczające poza klasycznie pojmowane pośrednictwo. Do takich czynności zalicza się m.in. czynności związane $z$ zarządzeniem ryzykiem (np. monitoring, techniczna ocena ryzyka czy wybór metody kontroli ryzyka), opracowywanie programów ubezpieczeniowych, przygotowywanie licznych analiz i opinii, bardzo ceniona przez klientów pomoc w dochodzeniu roszczeń od zakładów ubezpieczeń czy szeroko rozumiane doradztwo ubezpieczeniowe i prawne ${ }^{49}$.

\section{STRESZCZENIE}

Wpływ dyrektywy w sprawie dystrybucji ubezpieczeń na krajowy rynek pośrednictwa ubezpieczeniowego.

Zagadnienia wybrane

Artykuł stanowi analizę wpływu dyrektywy w sprawie dystrybucji ubezpieczeń na krajowy rynek ubezpieczeniowy. Zostają omówione zarówno charakterystyka oraz cel przyjęcia przedmiotowej dyrektywy, jak i stosunek zachodzący pomiędzy nią a dyrektywą w sprawie pośrednictwa ubezpieczeniowego, która straci ważność w 2018 r. Wśród przedstawionych kwestii znajdują się zakres przedmiotowy i podmiotowy stosowania dyrektywy dystrybucyjnej oraz wprowadzone w wyniku jej uchwalenia obowiązki informacyjne nałożone na pośredników ubezpieczeniowych. Ostatnia część pracy została poświęcona kluczowym aspektom implementacji przedmiotowej dyrektywy w kontekście działalności brokera ubezpieczeniowego. W tej kwestii stwierdzono, że wprowadzenie analizowanej dyrektywy do krajowego porządku normatywnego nie musi być szczególnie skomplikowane, nawet w kontekście funkcjonującego, podmiotowego podziału pośredników ubezpieczeniowych. Zauważono także, iż niektóre $z$ wymogów zawartych $\mathrm{w}$ dyrektywie dystrybucyjnej funkcjonują w prawie polskim.

49 E. Kowalewski, Prawo ubezpieczeń gospodarczych, Bydgoszcz-Toruń 2006, s. $443-447$. 
Słowa kluczowe: dyrektywa dystrybucyjna; dyrektywa w sprawie pośrednictwa ubezpieczeniowego; pośrednictwo ubezpieczeniowe; broker

\section{SUMMARY}

The impact of insurance distribution directive on domestic insurance intermediary market. Selected issues

The article covers the analysis of the impact of the Insurance Distribution Directive (IDD) on Polish insurance market. Both characteristics and purpose of the IDD, as well as the relations between this directive and Insurance Mediation Directive, which expires in 2018, are discussed. Among presented issues are the subject-object scope of the IDD and introduced, as a result of its adoption, information disclosure requirements which are imposed on insurance intermediaries. The last part of the paper is devoted to key aspects of the application of the IDD in the context of activities of insurance brokers. In this matter, it has been stated that the implementation of analyzed directive into Polish legal order not need to be especially complicated, even in the light of functioning, subjective division of insurance intermediaries. Moreover, it was also noticed that some of the IDD requirements exist at Polish law.

Keywords: insurance Distribution Directive; insurance mediation directive; insurance intermediary; broker

\section{BIBLIOGRAFIA}

Better Regulation, Insurance Distribution Directive (IDD), http: / /www.betterregulation.com/ie/hot-topic/imd2 (dostęp: 10.07.2016 r.).

Dunaj B., Nowy słownik języka polskiego, Warszawa 2005.

Encyklopedia Zarządzania - „dystrybutor”, https://mfiles.pl/pl/index. php/Dystrybutor (dostęp: 10.07.2016 r.).

Galewska E., Implementacja dyrektyw telekomunikacyjnych, Warszawa 2007.

Gazeta Ubezpieczeniowa, KNF: Ponad 200 tys. agentów i OWCA w 2014 r., http: / / www.gu.com.pl/index.php?option=com_content\&view=article\&id=55719:2015-03-18-07-32-07\&catid=99:porednictwo\&Itemid=102 (dostęp: 10.07.2016 r.). 
Gnela B., Ochrona konsumenta usług finansowych. Wybrane zagadnienia prawne, Warszawa 2007.

Kluczowe kwestie IMD 2, Dokument BIPAR, http://www.polbrokers.pl/ problemy_prawne, (dostęp: 10.07.2016 r.).

Kowalewski E., Prawo ubezpieczeń gospodarczych, Bydgoszcz-Toruń 2006.

Kowalewski E., Ziemiak M.P., Ustawa reklamacyjna a obrót ubezpieczeniowy (część I), „Wiadomości Ubezpieczeniowe” 2015, nr 3.

Kubuj K., Implementacja prawa wspólnotowego na tle doświadczeń Francji, Warszawa 2006.

Malinowska K., Konflikt interesów $w$ działalności brokerskiej $w$ świetle obowiazujaccego prawa i tendencji europejskich, w: Konkurencja i konkurencyjność na rynku ubezpieczeniowym, red. M. Serwach, Warszawa 2015.

Mik C., Metodologia implementacji europejskiego prawa wspólnotowego $w$ krajowych porzadkach prawnych, w: Implementacja prawa integracji europejskiej $w$ krajowych porzadkach prawnych, red. C. Mik, Toruń 1998.

Project Group "Principles of Reinsurance Contract Law" Report on the $1^{\text {st }}$ Workshop, January 27-30 Zurich, https://www.editoraroncarati.com. br/v2/phocadownload/reuniao_zurique_janeiro_2016_relatorio_basico. pdf (dostęp: 16.08.2016 r.).

Project Group "Restatement of European Insurance Contract Law", The Principles of European Insurance Contract Law (PEICL) - Version 2015, https://www.uibk.ac.at/zivilrecht/forschung/evip/restatement/draft. html (dostęp: 16.08.2016 r.).

Pawlak P., Marszelewski M., Ustawa reklamacyjna z perspektywy rynku ubezpieczeń gospodarczych, w: Państwo a gospodarka. Prawna regulacja podejmowania i prowadzenia działalności gospodarczej, red. H. Nowicki, P. Nowicki, Torun 2016.

Piątkowski P., „Broker w świetle Insurance Distribution Directive”, praca magisterska napisana pod kierunkiem prof. dr. hab. E. Kowalewskiego, Toruń 2016.

Podstawy prawa Unii Europejskiej z uwzględnieniem Traktatu z Lizbony, red. J. Galster, Toruń 2010.

Pokrzywniak J., Ustawa o pośrednictwie ubezpieczeniowym - ocena i uwagi „de lege ferenda” $w$ kontekście prac nad nowelizacja dyrektywy $w$ sprawie pośrednictwa ubezpieczeniowego, w: Ubezpieczenia gospodarcze. Wybrane zagadnienia prawne, red. B. Gnela, Warszawa 2011.

Polski Związek Pracodawców Prawniczych, Wnioski z prac Zespołu ds. Etyki przy Polskim Związku Pracodawców Prawniczych, http://www.pracodawcyprawniczy.org.pl/dokumenty.html (dostęp: 16.08.2016 r.).

Rzecznik Finansowy, Sprawozdanie Rzecznika Finansowego za 2015 r., Warszawa 2016. 
Tereszkiewicz P., Obowiazki informacyjne $w$ umowach o ustugi finansowe, Warszawa 2015.

The European Federation of Insurance Intermediaries, BIPAR views on the revision of the IMD, https://www.wko.at/Content.Node/branchen/t/ sparte_iuc/Versicherungsmakler-und-Berater-in-Versicherungsangelegenheiten/BIPAR_views_on_the_IMD-revision_Oct2011_4.pdf (dostęp: 10.07.2016 r.).

The Free Dictionary - level playing field, http://idioms.thefreedictionary. com/level+playing+field (dostęp: 10.07.2016 r.).

Urząd Komisji Nadzoru Finansowego, Raport o stanie rynku brokerskiego w 2014 r., Warszawa 2015.

Wojno B., Przedmiotowy zakres pośrednictwa ubezpieczeniowego, w: Ubezpieczenia gospodarcze. Wybrane zagadnienia prawne, red. B. Gnela, Warszawa 2011.

Zoń Ł., Deregulacja zawodu brokera ubezpieczeniowego i reasekuracyjnego, „Prawo Asekuracyjne” 2014, nr 3.

Zoń Ł., Konsument - tak, konsumeryzm - nie, „Gazeta Ubezpieczeniowa” maj 2014, nr 21.

Zoń Ł., Refleksje prawnika i brokera nad nową europejską dyrektywa o pośrednictwie ubezpieczeniowym, http: / /www.eib.com.pl/uploads/news / lukasz\%20zon\%20o\%20imd2.pdf (dostęp: 10.07.2016 r.). 
